\title{
OXIDATIVE STRESS PARAMETERS IN RATS EXPOSED TO FLUORIDE AND ASPIRIN
}

\author{
I Inkielewicz, ${ }^{\text {a,b }}$ W Czarnowski ${ }^{a}$ \\ Gdańsk, Poland
}

SUMMARY: The action of fluoride (F) and aspirin (acetylsalicylic acid, ASA) administered separately and together on oxidative stress parameters and on $F$ excretion in rats was studied over a period of six weeks. Thirty adult male Wistar rats were divided into five equal groups of six each: (I) controls receiving tap water; (II) controls receiving intragastrically $1 \mathrm{~mL}$ of tap water (once a day); (III) animals receiving $25 \mathrm{mg} \mathrm{F/L}$ in their drinking water; (IV) animals receiving $35 \mathrm{mg} \mathrm{ASA} / \mathrm{kg} \mathrm{bw/}$

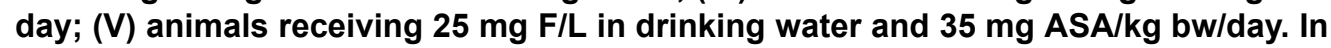
rats treated only with fluoride the $F$ excretion in urine significantly increased in an exposure time-dependent manner and decreased both in rats treated with ASA and co-exposed to ASA and F. In animals treated with ASA alone, the activity of glutathione peroxidase (GPx) and the concentrations of glutathione (GSH) and thiobarbituric acid reactive substances (TBARS) increased in brain, liver and blood, whereas the activity of catalase (CAT) decreased in liver and erythrocytes, but increased in liver. In rats exposed to $F$ alone the concentration of GSH and the activities of GPX and CAT decreased, whereas the concentration of TBARS significantly increased in liver, brain, kidney and blood. In rats co-exposed to $F$ and ASA, the concentrations of GSH and TBARS and the activities of GPX and CAT (except in liver) were higher than in animals receiving only $F$.

Keywords: Antioxidant potential; Aspirin treatment; Fluoride and aspirin; Fluoride in urine; Lipid peroxidation; Rats and aspirin.

\section{INTRODUCTION}

People are often exposed to many chemical substances that are deleterious and dangerous to health. Nowadays one pays attention not only to the effects of toxic xenobiotics but also to their interactions with one another. ${ }^{1-2}$ Particularly important are interactions between such toxicants to which exposure is the most common. Examples of such substances are fluoride (F) and aspirin.

In recent years, many studies have indicated that $\mathrm{F}$ induces free radical toxicity in humans and animals. ${ }^{3-6}$ It is well known that the metabolism and toxicity of $\mathrm{F}$ may be modified by a great many factors, including xenobiotics. ${ }^{7-9}$ Aspirin (2acetylsalicylic acid, ASA) is the most popular medicine in the world. ASA has been used as an analgesic, anti-inflammatory, and antipyretic substance. In low doses taken for a long time, ASA will have anticoagulant activity. ${ }^{10-11}$ At present there are several scientific reports about the effect of ASA on antioxidant potential. ${ }^{12-14}$ However, there does not appear to be any information available in the literature about interactions between F and ASA in soft tissues.

The aim of this study was to investigate the impact of F and ASA on free radical mediated parameters and on urinary $\mathrm{F}$ excretion in rats when given separately and together in a 6-week experiment

\footnotetext{
${ }^{\mathrm{a} D e p a r t m e n t}$ of Toxicology, Medical University of Gdańsk. ${ }^{\mathrm{b}}$ For correspondence: Dr Iwona Inkielewicz, Department of Toxicology, Medical University of Gdańsk. 80-416 Gdańsk, Al. Gen. Hallera 107, Poland; E-mail: iinkiel@amg.gda.pl.
} 


\section{MATERIALS AND METHODS}

Animals and experimental design: The experiment was carried out for 6 weeks. Thirty adult male Wistar rats weighing $189 \pm 6.9 \mathrm{~g}$ were kept under standard laboratory conditions (temperature $22 \pm 2^{\circ} \mathrm{C}$ in natural light-dark cycle, humidity $60 \%$ ). All animals were fed on a standard laboratory pellet diet containing $0.7 \mathrm{mg}$ water-extractable $\mathrm{F} / \mathrm{kg}$. The rats were divided into five groups:

I.Controls drinking tap water containing $0.3 \mathrm{mg} \mathrm{F} / \mathrm{L}$

II.Controls receiving intragastrically $1 \mathrm{~mL}$ tap water once a day by a stomach tube

III.Exposed animals receiving $25 \mathrm{mg} \mathrm{F}$ (from $\mathrm{NaF}$ )/L in drinking water

IV.Exposed animals receiving $35 \mathrm{mg} \mathrm{ASA} / \mathrm{kg}$ bw/day (in $1 \mathrm{~mL}$ of water once a day by a stomach tube)

V. Exposed animals receiving $25 \mathrm{mg} \mathrm{F} / \mathrm{L}$ in drinking water and $35 \mathrm{mg} \mathrm{ASA} / \mathrm{kg}$ $\mathrm{bw} /$ day (in $1 \mathrm{~mL}$ of water once a day by a stomach tube)

Water consumption by the animals was measured daily; body weight was measured once a week. Every week 4 rats of each group were placed into metabolic cages, and their 24-hr urine samples were collected. After 6 weeks of exposure, the animals of each group were sacrificed, and samples of blood, brain, kidney, and liver were collected. Blood was taken with an anticoagulant by cardiac puncture.

Analytical procedures: The concentration of fluoride in the urine was determined potentiometrically after dilution with equal volumes of TISAB buffer by a $\mathrm{F}$ ion-specific electrode (Orion) and $\mathrm{Ag} / \mathrm{AgCl}$ reference electrode. ${ }^{15}$ Urinary creatinine was determined by the method of Folin and Morris. ${ }^{16}$ Urinary $\mathrm{F}$ is reported as $\mathrm{mg} \mathrm{F} / \mathrm{g}$ creatinine. The accuracy of measurements was assessed with reference materials - Seronorm Control Urine (Nycomed Pharma AC, Oslo, Norway). Mean F recovery was $98.9 \%$. In tissue homogenates and blood (or plasma) the activity of glutathione peroxidase (GPx) was determined according to Paglia and Valentine, ${ }^{17}$ the activity of catalase (CAT) according to Aebi, ${ }^{18}$ the concentration of glutathione (GSH) by the method of Sedlak and Lindsay, ${ }^{19}$ and the concentration of thiobarbituric acid reactive substances (TBARS) according to Rice et al. ${ }^{20}$ The protein content in plasma, kidney, liver, and brain was determined by the method of Lowry et al. ${ }^{21}$ Hemoglobin content in blood was determined by the method of Drabkin. ${ }^{22}$

Statistical analysis: Data are given as means \pm standard error. Statistical analysis was performed using the Fisher-Snedecor and Student's t test.

\section{RESULTS}

Results of water consumption and fluoride intake by the five groups of rats are presented in Table 1. In this experiment decreased water consumption was noticed only in the ASA group, whereas in the F and F plus ASA groups water consumption did not change. 
Table 1. Water consumption and fluoride intake

\begin{tabular}{llcc}
\hline $\begin{array}{c}\text { Group treatment of } \\
\text { animals }\end{array}$ & $\begin{array}{c}\text { Water consumption mL/24 hr } \\
\text { Means } \pm \text { SD }\end{array}$ & $\begin{array}{c}\mathrm{F} \text { intake mg F/24 hr/rat } \\
\text { Means }\end{array}$ \\
\hline I & Controls & $36.6 \pm 2.6$ & 0.011 \\
II & Controls (i.g.) & $34.5 \pm 2.5$ & 0.010 \\
III & F & $35.9 \pm 4.1$ & 0.897 \\
IV & ASA & $31.8 \pm 3.2$ & 0.009 \\
V & F+ASA & $37.7 \pm 3.9$ & 0.943 \\
\hline
\end{tabular}

$\mathrm{F}$ concentration in urine is given in Table 2. Exposure to NaF resulted in a significant increase in $\mathrm{F}$ excretion in urine. In animals exposed only to ASA, urinary $\mathrm{F}$ excretion decreased markedly. Likewise, co-exposure to $\mathrm{F}$ and ASA significantly decreased the $\mathrm{F}$ excretion, when compared to animals treated only with F.

Table 2. Fluoride concentration in urine (mg F/g creatinine $\pm S D$ )

\begin{tabular}{lcccccc}
\hline \multirow{2}{*}{$\begin{array}{c}\text { Group treatment } \\
\text { of a nimals }\end{array}$} & \multicolumn{6}{c}{ Exposure time in weeks } \\
\cline { 2 - 7 } & 0 & 1 & 2 & 3 & 4 & 5 \\
\hline I Controls & $2.56 \pm 0.168$ & $2.12 \pm 0.456$ & $2.54 \pm 0.911$ & $2.98 \pm 0.378$ & $3.42 \pm 0.096$ & $3.04 \pm 0.009$ \\
II Controls & $2.09 \pm 0.061$ & $2.47 \pm 0.087$ & $2.48 \pm 0.349$ & $2.63 \pm 0.281$ & $2.87 \pm 0.118$ & $2.98 \pm 0.418$ \\
(i.g.) & & & & & & \\
III F & $3.98 \pm 0.264$ & $5.36 \pm 0.910$ & $6.78 \pm 0.491$ & $7.74 \pm 1.246$ & $8.49 \pm 0.692$ \\
IV ASA & $1.89 \pm 0.034$ & $1.46 \pm 0.049$ & $1.68 \pm 0.413$ & $1.34 \pm 0.061$ & $1.26 \pm 0.411$ \\
V F+ASA & $3.48 \pm 1.094$ & $4.34 \pm 1.456$ & $5.01 \pm 0.986$ & $5.63 \pm 1.109$ & $6.27 \pm 1.031$ \\
\hline
\end{tabular}

\begin{tabular}{llllll}
\hline \multicolumn{2}{l}{ Statistical significance (values are for 4 animals in each group): } & & \\
I vs. III & $p<0.01 \uparrow$ & $p<0.001 \uparrow$ & $p<0.001 \uparrow$ & $p<0.001 \uparrow$ & $p<0.001 \uparrow$ \\
II vs. IV & n.s. & $p<0.05 \downarrow$ & $p<0.05 \downarrow$ & $p<0.05 \downarrow$ & $p<0.01 \downarrow$ \\
I vs. V & $p<0.05 \uparrow$ & $p<0.001 \uparrow$ & $p<0.001 \uparrow$ & $p<0.001 \uparrow$ & $p<0.001 \uparrow$ \\
II vs. V & $p<0.05 \uparrow$ & $p<0.01 \uparrow$ & $p<0.001 \uparrow$ & $p<0.001 \uparrow$ & $p<0.001 \uparrow$ \\
III vs. V & n.s. & $p<0.05 \downarrow$ & $p<0.01 \downarrow$ & $p<0.01 \downarrow$ & $p<0.01 \downarrow$ \\
IV vs. V & $p<0.01 \uparrow$ & $p<0.001 \uparrow$ & $p<0.001 \uparrow$ & $p<0.001 \uparrow$ & $p<0.001 \uparrow$
\end{tabular}

The activity of glutathione peroxidase (GPx) and the concentration of glutathione (GSH) are presented in Table 3 and Table 4, respectively. In this experiment, the GPx activity decreased significantly in brain and blood of animals treated only with F and co-exposed to F and ASA. However, the decrease in coexposed animals was smaller than in animals intoxicated only with $\mathrm{F}$.

The concentration of reduced glutathione (GSH) decreased significantly in kidney, liver, and blood of rats exposed to F. The decrease was lower in animals co-exposed to F and ASA. On the other hand, in animals given only ASA the concentration of GSH markedly increased.

The activity of catalase (CAT) is presented in Table 5. Catalase activity decreased in kidney, liver, brain, and erythrocytes of animals treated only with F. In rats given only ASA and in co-exposed animals the CAT activity decreased in liver and erythrocytes, but increased in kidney. 
Table 3. Activity of glutathione peroxidase in tissues (U/g protein) and blood $(\mathrm{U} / \mathrm{gHb})$

\begin{tabular}{llcccc}
\hline $\begin{array}{c}\text { Group treatment of } \\
\text { animals }\end{array}$ & $\begin{array}{c}\text { Kidney } \\
\text { mean } \pm \text { SD }\end{array}$ & $\begin{array}{c}\text { Liver } \\
\text { mean } \pm \text { SD }\end{array}$ & $\begin{array}{c}\text { Brain } \\
\text { mean } \pm S D\end{array}$ & $\begin{array}{c}\text { Blood } \\
\text { mean } \pm S D\end{array}$ \\
\hline I & Controls & $17.5 \pm 2.24$ & $42.0 \pm 6.65$ & $3.96 \pm 0.60$ & $2.10 \pm 0.39$ \\
II & Controls (i.g.) & $17.8 \pm 3.64$ & $39.9 \pm 5.81$ & $4.09 \pm 0.58$ & $1.98 \pm 0.41$ \\
III & F & $12.0 \pm 0.60$ & $35.7 \pm 3.04$ & $1.29 \pm 0.01$ & $1.35 \pm 0.34$ \\
IV & ASA & $20.9 \pm 4.31$ & $44.1 \pm 2.88$ & $4.35 \pm 0.45$ & $2.29 \pm 0.18$ \\
V & F+ASA & $16.8 \pm 1.55$ & $36.4 \pm 0.80$ & $2.33 \pm 0.30$ & $1.77 \pm 0.09$
\end{tabular}

Statistical significance (values are for 6 animals in each group):

I vs. III

II vs. IV

I vs. V

II vs. V

III vs. V

IV vs. V

p $<0.01 \downarrow \quad$ n.s.

n.s.

n.s.

n.s.

$p<0.01 \uparrow$

n.s.

n.s.

n.s.

n.s.

n.s.

\section{$p<0.001 \downarrow$}

$p<0.02 \downarrow$

$p<0.001$ n.s.

$p<0.01 \downarrow$

$p<0.01 \downarrow$

$p<0.01 \uparrow$

n.s.

$p<0.05 \downarrow$ $p<0.05 \downarrow$ $p<0.05 \uparrow$ $p<0.001 \downarrow \quad p<0.01 \downarrow$

Table 4. Concentration of glutathione in tissues ( $\mu \mathrm{M} / \mathrm{g}$ protein) and blood $(\mu \mathrm{M} / \mathrm{gHb})$

\begin{tabular}{llcccc}
\hline $\begin{array}{c}\text { Group treatment of } \\
\text { animals }\end{array}$ & $\begin{array}{c}\text { Kidney } \\
\text { mean } \pm \text { SD }\end{array}$ & $\begin{array}{c}\text { Liver } \\
\text { mean } \pm \text { SD }\end{array}$ & $\begin{array}{c}\text { Brain } \\
\text { mean } \pm \text { SD }\end{array}$ & $\begin{array}{c}\text { Blood } \\
\text { mean } \pm \text { SD }\end{array}$ \\
\hline I & Controls & $26.9 \pm 2.02$ & $57.7 \pm 8.02$ & $30.0 \pm 5.62$ & $5.45 \pm 0.28$ \\
II & Controls (i.g.) & $24.6 \pm 0.96$ & $54.6 \pm 7.41$ & $28.6 \pm 5.89$ & $5.09 \pm 0.43$ \\
III & F & $19.3 \pm 2.41$ & $41.2 \pm 7.92$ & $24.6 \pm 4.42$ & $4.03 \pm 0.15$ \\
IV & ASA & $27.4 \pm 4.67$ & $82.1 \pm 8.42$ & $34.1 \pm 2.54$ & $7.02 \pm 0.56$ \\
V & F+ASA & $24.2 \pm 0.82$ & $48.3 \pm 3.99$ & $27.7 \pm 2.07$ & $5.11 \pm 0.16$ \\
\hline
\end{tabular}

Statistical significance (values are for 6 animals in each group):

$\begin{array}{lllll}\text { I vs. III } & p<0.001 \downarrow & p<0.01 \downarrow & \text { n.s. } & p<0.001 \downarrow \\ \text { II vs. IV } & p<0.02 \uparrow & p<0.001 \uparrow & \text { n.s. } & p<0.001 \uparrow \\ \text { I vs. V } & p<0.02 \downarrow & p<0.05 \downarrow & \text { n.s. } & \text { n.s. } \\ \text { II vs. V } & \text { n.s. } & p<0.05 \downarrow & \text { n.s. } & \text { n.s. } \\ \text { III vs. V } & p<0.01 \uparrow & \text { n.s. } & \text { n.s. } & p<0.001 \uparrow \\ \text { IV vs. V } & \text { n.s. } & p<0.001 \downarrow & p<0.01 \downarrow & p<0.001 \downarrow\end{array}$

Table 5. Catalase activity in tissues ( $\mathrm{k} / \mathrm{mg}$ prote in) and erythro cytes $(\mathrm{k} / \mathrm{mg} \mathrm{Hb})$

\begin{tabular}{llcccc}
\hline $\begin{array}{c}\text { Group treatment of } \\
\text { animals }\end{array}$ & $\begin{array}{c}\text { Kidney } \\
\text { mean } \pm \text { SD }\end{array}$ & $\begin{array}{c}\text { Liver } \\
\text { mean } \pm \text { SD }\end{array}$ & $\begin{array}{c}\text { Brain } \\
\text { mean } \pm \text { SD }\end{array}$ & $\begin{array}{c}\text { Erythrocytes } \\
\text { mean } \pm \text { SD }\end{array}$ \\
\hline I & Controls & $0.580 \pm 0.09$ & $2.58 \pm 0.232$ & $7.27 \cdot 10^{-3} \pm 6.2410^{-4}$ & $24.3 \pm 3.13$ \\
II & Controls (i.g.) & $0.479 \pm 0.04$ & $2.76 \pm 0.196$ & $6.94 \cdot 10^{-3} \pm 6.71 \cdot 10^{-4}$ & $25.9 \pm 3.41$ \\
III & F & $0.458 \pm 0.08$ & $1.03 \pm 0.152$ & $1.09 \cdot 10^{-3} \pm 9.27 \cdot 10^{-4}$ & $17.5 \pm 1.52$ \\
IV & ASA & $0.794 \pm 0.03$ & $1.99 \pm 0.377$ & $6.69 \cdot 10^{-3} \pm 8.24 \cdot 10^{-4}$ & $18.7 \pm 3.06$ \\
V & F+ASA & $0.625 \pm 0.02$ & $0.63 \pm 0.076$ & $6.58 \cdot 10^{-3} \pm 6.78110^{-4}$ & $18.2 \pm 3.41$
\end{tabular}

Statistical significance (values are for 6 animals in each group):

$\begin{array}{lllll}\text { I vs. III } & p<0.02 \downarrow & p<0.001 \downarrow & p<0.001 \downarrow & p<0.01 \downarrow \\ \text { II vs. IV } & p<0.01 \uparrow & p<0.05 \downarrow & \text { n.s. } & p<0.05 \downarrow \\ \text { I vs. V } & \text { n.s. } & p<0.001 \downarrow & p<0.01 \downarrow & p<0.05 \downarrow \\ \text { II vs. V } & p<0.01 \uparrow & p<0.001 \downarrow & \text { n.s. } & p<0.05 \downarrow \\ \text { III vs. V } & p<0.01 \uparrow & p<0.05 \downarrow & p<0.001 \uparrow & \text { n.s. } \\ \text { IV vs. V } & \text { n.s. } & p<0.001 \downarrow & \text { n.s. } & \text { n.s. }\end{array}$




\begin{tabular}{llcccc}
\multicolumn{5}{c}{ Table 6. TBARS concentration in tissues and plasma $(\mu \mathrm{M} / \mathrm{g}$ protein $)$} \\
\hline $\begin{array}{l}\text { Group treatment of } \\
\text { animals }\end{array}$ & $\begin{array}{c}\text { Kidney } \\
\text { mean } \pm \text { SD }\end{array}$ & $\begin{array}{c}\text { Liver } \\
\text { mean } \pm \text { SD }\end{array}$ & $\begin{array}{c}\text { Brain } \\
\text { mean } \pm \text { SD }\end{array}$ & $\begin{array}{c}\text { Plasma } \\
\text { mean } \pm \text { SD }\end{array}$ \\
\hline I & Controls & $4.16 \pm 0.436$ & $5.39 \pm 0.31$ & $16.83 \pm 1.94$ & $9.06 \pm 0.54$ \\
II & Controls (i.g.) & $4.06 \pm 0.396$ & $5.21 \pm 0.41$ & $15.93 \pm 1.43$ & $8.99 \pm 0.41$ \\
III & F & $19.85 \pm 4.23$ & $16.25 \pm 1.96$ & $67.14 \pm 4.65$ & $11.27 \pm 0.98$ \\
IV & ASA & $19.66 \pm 3.89$ & $17.66 \pm 0.41$ & $31.00 \pm 7.50$ & $11.62 \pm 1.15$ \\
V & F+ASA & $73.46 \pm 3.98$ & $78.24 \pm 9.71$ & $103.39 \pm 12.6$ & $63.67 \pm 6.24$ \\
\hline Statistical significance & $($ values are for 6 animals in & ach group $):$ & \\
I vs. III & $p<0.001 \uparrow$ & $p<0.001 \uparrow$ & $p<0.001 \uparrow$ & $p<0.05 \uparrow$ \\
II vs. IV & $p<0.001 \uparrow$ & $p<0.001 \uparrow$ & $p<0.01 \uparrow$ & $p<0.05 \uparrow$ \\
I vs. V & $p<0.001 \uparrow$ & $p<0.001 \uparrow$ & $p<0.001 \uparrow$ & $p<0.001 \uparrow$ \\
II vs. V & $p<0.001 \uparrow$ & $p<0.001 \uparrow$ & $p<0.001 \uparrow$ & $p<0.001 \uparrow$ \\
III vs. V & $p<0.001 \uparrow$ & $p<0.001 \uparrow$ & $p<0.001 \uparrow$ & $p<0.001 \uparrow$ \\
IV vs. V & $p<0.001 \uparrow$ & $p<0.001 \uparrow$ & $p<0.001 \uparrow$ & $p<0.001 \uparrow$
\end{tabular}

Concentrations of TBARS are given in Table 6. TBARS concentrations increased significantly in all investigated tissues of animals exposed to $\mathrm{F}$ as well as to ASA. In co-exposed animals the TBARS concentrations markedly increased when compared to animals treated with single substances.

\section{DISCUSSION}

The exposure of rats to $25 \mathrm{mg} \mathrm{F} / \mathrm{L}$ in their drinking water in this study corresponds to human environmental exposure in areas with high $\mathrm{F}$ in the drinking water or in F-polluted occupational conditions. ${ }^{7}$

Decreased water consumption was noticed in this study only in the ASA group. ASA as a typical NSAIDS (Nonsteroidal Anti-Inflammatory Drug) is nephrotoxic and consequently may cause even oliguria, ${ }^{23}$ whereas in the $\mathrm{F}$ and F plus ASA groups water consumption did not change.

As expected, in this study exposure to $\mathrm{NaF}$ resulted in a significant increase of $\mathrm{F}$ excretion in urine ${ }^{32}$ The increase changed in an exposure-time-dependent manner. In animals exposed only to ASA, urinary F excretion markedly decreased. This may be caused by the fact that both F and ASA compete for the same anion transport system in the renal tubules. ${ }^{33}$ Indeed, in co-exposed animals, F excretion was significantly decreased, when compared to rats exposed only to $F$.

In this study the activity of GPx and the concentration of GSH in all investigated tissues is the lowest in rats exposed only to $\mathrm{F}$, intermediate in co-exposed animals, and the highest in rats treated only with ASA. These results are consistent with our previous studies performed on animals exposed to $\mathrm{F}^{24-25,27} \mathrm{~A}$ decrease in the activity of GPx, CAT, and SOD has been found in tissues of experimental animals exposed to $\mathrm{F}$ compounds and in people living in endemic areas. ${ }^{3-6}$ On the other hand, Kirkova et al. ${ }^{26}$ ascertained that GPx activity did not change in animals treated with ASA. 
The intermediate activities of $\mathrm{GP}_{\mathrm{x}}$ and the concentrations of GSH in this study found in co-exposed animals could mean that ASA minimized the toxic effects of F. However, the mechanism of action of aspirin (ASA) with regard to oxidative stress is not fully understood. Available data indicate that it may involve a decrease of superoxide anion production. ${ }^{14}$

Also, the activity of catalase in this study in most tissues behaved similarly to that of GPx. However, it increased in kidney of animals treated with ASA. In a previous study we found that CAT activity decreased in rats exposed to $\mathrm{F}^{28}$ Kirkova et al. ${ }^{26}$ stated that higher aspirin concentration $(5.0 \mathrm{mM})$ inhibited the activity of this enzyme.

Many researchers independently have confirmed enhanced lipid peroxidation caused by F. ${ }^{4-6,29}$ On the other hand, some authors have reported that $\mathrm{F}$ does not impair antioxidant defense systems. ${ }^{30,31}$ Kirkova et al. ${ }^{26}$ observed that ASA in low concentrations stimulated the formation of malondialdehyde in liver homogenates but in higher concentrations it inhibited this process. However, Steer et al. ${ }^{13}$ affirmed that aspirin both in vivo and in vitro protects LDL (low-density lipoproteins) against subsequent oxidative modification, thereby providing an additional mechanism whereby aspirin may protect against atherosclerosis. Schwarz et al. ${ }^{12}$ reported that ASA intensifies MDA (malondialdehyde) production in hepatic microsomes and mitochondria. In our study we noticed that the TBARS concentration significantly increased in all investigated tissues of animals exposed both to F and ASA. However, combined exposure caused a marked increase of lipid peroxidation in liver, brain, kidney, and plasma.

In conclusion, our study indicates that F and ASA administered both singly and together participate in free radical-mediated reactions and affect antioxidant parameters. The changes in the activity of GPx and CAT and the concentration of GSH suggest that ASA counteracts the toxic effects of $F$ on antioxidant parameters. An interesting further observation was that ASA decreases F excretion in urine.

\section{ACKNOWLEDGMENT}

This study was supported by Grant 134 from Medical University in Gdańsk. We wish to thank Professor Jerzy Krechniak for his invaluable suggestions and comments during the course of this study.

\section{REFERENCES}

1 Seńczuk W, editor. Modern toxicology.1st ed. Warsaw: PZWL; 2005. [In Polish].

2 Wang A, Xia T, Ru R, Yuan J, Chen X, Yang K. Antagonistic effect of selenium on oxidative stress, DNA damage and apoptosis induced by fluoride in human hepatocytes. Fluoride 2004;37:107-16.

3 Kaushik T, Shyam R, Vats P, Suri S, Kumria MML, Sharma PC, et al. Glutathione metabolism in rats exposed to high-fluoride water and effect of spirulina treatment. Fluoride 2001;34:132-8.

4 Guan ZZ, Xiao KQ, Zeng XY, Long YG, Cheng YH, Jiang SF, et al. Changed cellular membrane lipid composition and lipid peroxidation of kidney in rats with chronic fluorosis. Arch Toxicol 2000;74:602-8.

5 Kalyanalakshmi P, Vijayabhaskar M, Naidu MD. Lipid peroxidation and antioxidant enzyme status of adult males with skeletal fluorosis in Andhra Pradesh, India. Fluoride 2007;40:42-5. 
6 Shivarajashankara YM, Shivashankara AR, Bhat PG, Rao SH. Effect of fluoride intoxication on lipid peroxidation and antioxidant systems in rats. Fluoride 2001;34:108-13.

7 World Health Organization. Environmental Health Criteria, 227 Fluorides, IPS. Geneva: World Health Organization; 2002.

8 Rao GS. Dietary intake and bioavailability of fluoride [review]. Annu Rev Nutr 1984;4:115-36.

9 Trautner K, Einwag J. Influence of milk and food on fluoride bioavailability from $\mathrm{NaF}$ and $\mathrm{Na}_{2} \mathrm{FPO}_{3}$ in man. J Dent Res 1989;68:72-7.

10 Mastalerz L, Setkowicz M, Szczeklik A. Mechanism of chronic urticaria exacerbation by aspirin. Cerr Allergy Asthma Rep 2005;5:277-83.

11 Radomski M W, Gordon P A, Radomski A, Armstrong P W. Modulation by aspirin of platelet aggregation pathways. Can J Cardiol 2000;16 Suppl F:S221.

12 Schwarz KB, Arey BJ, Tolman K, Mahanty S. Iron chelation as a possible mechanism for aspirininduce malondialdehyde production by mouse liver microsomes and mitochondria. J Clin Invest 1988;81:165-70.

13 Steer KA, Wallace TM, Bolton $\mathrm{CH}$, Hartog M. Aspirin protects low density lipoprotein from oxidative modification. Heart 1997;77:333-7.

14 Wu R, Laplante MA, de Champlain J. Antioxidative properties of acetylsalicylic acid on vascular tissues from normotensive and spontaneously hypertensive rats. Circulation 2002;105:387-92.

15 Czarnowski W, Wrześniowska K, Krechniak J. Fluoride in drinking water and human urine in Northern and Central Poland. Sci Total Environ 1996;191:177-84.

16 Folin $\mathrm{O}$, Morris $\mathrm{JL}$. On determination of creatine and creatinine in urine. J Biol Chem 1914;17:469-73.

17 Paglia DE, Valentine WN. Studies on the quantitative and qualitative characterization of erythrocyte glutathione peroxidase. J Lab Clin Med 1967;70:158-69.

18 Aebi HE. Catalase in vitro. Methods Enzymol 1984;105:121-6.

19 Sedlak I, Lindsay RH. Estimation of total, protein-bound and nonprotein sulphydryl groups in tissue with Ellman's reagent. Anal Biochem 1968;25:192-205.

20 Rice-Evans CA, Diplock AT, Symons MCR. Techniques in free radical research. Amsterdam: Elsevier;1991.

21 Lowry OH, Rosebrough NI, Fahr AL, Randall RJ. Protein measurement with the Folin phenol reagent. J Biol Chem 1951;193:265-75.

22 Drabkin DL, Austin JH. Spectrophotometric studies. Preparations from washed blood cells, nitric oxide haemoglobin and sulfhemoglobin. J Biol Chem 1935;112:51-65.

23 Murray MD, Brater DC. Renal toxicity of the nonsteroidal anti-inflammatory drugs. Annu Rev Pharmacol Toxicol 1993;32:435-65.

24 Inkielewicz I, Krechniak J. Impact of sodium fluoride on free radical damage and antioxidant potential in rats. Pol J Environ Stud 2003;12(Suppl.1):171-5.

25 Inkielewicz I, Krechniak J. Fluoride effects on glutathione peroxidase and lipid peroxidation in rats. Fluoride 2004;37:7-12.

26 Kirkova M, Ivancheva E, Russanov E. In vitro effects of aspirin on malondialdehyde formation and on activity of antioxidant and some metal-containing enzymes. Comp Biochem Physiol Pharmacol Toxicol Endocrinol 1994;108:145-52.

27 Krechniak J, Inkielewicz I. Correlations between fluoride concentrations and free radical parameters in soft tissues of rats. Fluoride 2005;38:293-6.

28 Inkielewicz I, Rogowska M, Krechniak J. Lipid peroxidation and antioxidant enzyme activity in rats exposed to fluoride and ethanol. Fluoride 2006;39:53-9.

29 Shanthakumari D, Srinivasalu S, Subramanian S. Effect of fluoride intoxication on lipid peroxidation and antioxidant status in experimental rats. Toxicology 2004;204:219-28.

30 Chlubek D. Fluoride and oxidative stress [editorial review]. Fluoride 2003;36:217-28.

31 Reddy GB, Khandare AL, Reddy PY, Rao GS, Balakrishna N, Srivalli I. Antioxidant defence system and lipid peroxidation in patients with skeletal fluorosis and fluoride-intoxicated rabbits. Toxicol Sci 2003;72:363-8.

32 Inkielewicz I, Krechniak J. Fluoride content in soft tissues and urine of rats exposed to sodium fluoride in drinking water. Fluoride 2003;36:263-6.

33 Pritchard JB, Miller DS. Mechanisms mediating renal secretion of organic anions and cations [review]. Physiol Rev 1993;73:765-96. 